DOI $10.23859 / 2587-8352-2018-2-1-5$

UDC 93

\title{
David Moon
}

Professor. Anniversary Professor in History, University of York, Dept of History, Vanbrugh College

Heslington, York david.moon@york.ac.uk

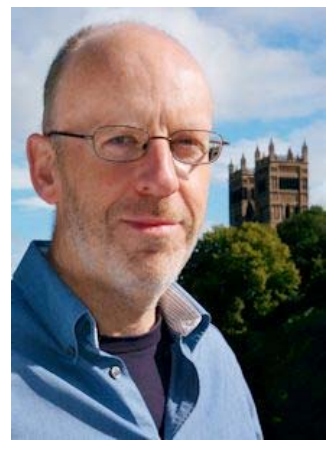

The international dissemination of Russian genetic soil science (pochvovedenie), 1870s - 1914

Abstract. This article considers the international dissemination of the Russian innovation of genetic soil science, devised by a team of scientists led by V. V. Dokuchaev in the 1870 s and 1880s, over the decades down to 1914. Russian soil science was disseminated by articles in foreign languages, exhibits at world fairs, papers read by Russian scientists at international conferences, visits by Russian soil scientists abroad and correspondence with foreign scientists. Acceptance came sooner in Europe, but took longer in the United States where, in spite of attempts to disseminate the innovation, it encountered institutional resistance.

Key words: soil Science, History of Science, Russia, Europe, United States, Dissemination

\section{Introduction}

In the 1870s and 1880s Russian soil scientists led by V.V. Dokuchaev devised new ways of understanding and analyzing soils. They called their new science "genetic soil science". At the heart of the new science was the idea that soils were a separate part of the natural world and merited study in their own right. Soil science was definitely not, in the view of the genetic soil scientists, a part of geology or simply a branch of agronomy. They understood that soils formed as a result of the interaction between different "soil forming factors": the mineral parent material; organic matter (vegetation and animal life); the climate (especially precipitation and temperature); the topography of the region; over time. These factors and the process of soil formation could be analyzed by studying cross sections, or "profiles", of soil to see the different layers, or "horizons", that developed over time, form the parent rock at the bottom to the fully formed soil at the top. Their research showed that different types of 
soil formed in different conditions. Understanding soils in the context of the conditions in which they had formed was essential to managing soils and laying the basis for sustainable use of this valuable natural resource. ${ }^{1}$

The Russian innovation became the basis for modern soil science around the world. Some scientists in other countries, for example E.W. Hilgard in the United States, had been working along similar lines and developed similar ideas, but none came up with a full theory to explain to the origins of different types of soils as a basis for their classification. ${ }^{2}$ By the middle of the twentieth century, as Jan Arend has argued, Russian soil science had become "classical". Arend has emphasized the importance of a book by Dokuchaev's student K.D. Glinka published in German in 1914 in the transfer to Russian soil science to the west. There is no doubt that Glinka's book was a breakthrough as it was the first full length monograph on Russian soil science to appear in a western European language. ${ }^{3}$ An important role in the internationalization of Russian soil science was played by international conferences and congresses of soil scientists. They began with small meetings in Budapest in Hungary in 1909 and Stockholm in Sweden in 1910. The conferences resumed after the First World War. In 1927 and 1930, the first two International Congresses of Soil Science were held in the United States and the Soviet Union. ${ }^{4}$ The process of assimilation of Russian soil science by scientists in other countries began at the end of the nineteenth century, and proceeded gradually, faster in some than others.

The aim of this article is to survey the efforts of Russian soil scientists to disseminate their new science around the world before Glinka's book and the international conferences facilitated the assimilation of the Russian innovation more widely. This article builds on the work of Russian scientist I.P. Vtorov ${ }^{5}$ by identifying further early works on Russian soil science in western European languages and by using materials from American archives and publications on the reception of Russian soil science in

${ }^{1}$ See Dokuchaev V.V. Russkii chernozem. St Petersburg, 1883; Krupenikov I.A. Istoriia pochvovedeniia: ot vremeni ego zarozhdeniia do nashikh dnei. Moscow, 1981); Dobrovol'skii G.V. Lektsii po istorii pochvovedeniia. Moscow, 2010.

${ }^{2}$ See Moon D. and Landa E.R. The Centenary of the Journal Soil Science: Reflections on the Discipline in the United States and Russia Around a Hundred Years ago. Soil Science, 2017, vol. 182, no. 6/7. (forthcoming).

${ }^{3}$ Arend J. Russlands Bodenkunde in der Welt. Eine ost-westliche Transfergeschichte 18801945. Göttingen, 2017, p. 314. Arend J. Russian Science in Translation: How pochvovedenie was brought to the West, c. 1875-1945. Kritika: Explorations in Russian and Eurasian History, 2017. (forthcoming); Glinka K. Die Typen der Bodenbildung: Ihre Klassifikation und Geographische Verbreitung. Berlin, 1914.

${ }^{4}$ Anon. History of the Organization of the International Society of Soil Science. Soil Science, 1928, vol. 25, no.1, pp. 3-4; Krupenikov, 1981, pp. 224-228.

${ }^{5}$ Vtorov I. P. Pervoe vospriiatie idei V.V. Dokuchaeva mezhdunarodnym nauchnym soobshchestvom. Unpublished paper presented to Mezhdunarodnyi nauchnyi seminar "Nauchnoe nasledie V.V. Dokuchaeva: traditsii i razvitie idei”. Moscow, 30-31 May 2016. 
the United States. Russian soil scientists sought to promote their work in several ways to bring it to the attention of their counterparts in other countries who did not read Russian. They prepared exhibits for the World's Fairs of the period in various countries, including France and the United States. Russian soil scientists presented papers at international conferences and met foreign scientists while on visits abroad. These activities contributed to the publication of a small but growing number of works on Russian soil science in western European languages. ${ }^{6}$ It will be shown that by 1914 soil scientists in Europe and North America already had opportunities to find out about the theories and methodologies of Russian soil scientists. While the ideas found a more receptive audience among some of their European counterparts, they encountered resistance among many soil scientists working for the U.S. government Bureau of Soils which was engaged in mapping the soils of the United States using a different methodology.

\section{Main body}

The first translation into a western European language of work by a Russian genetic soil scientist was a set of articles by Dokuchaev published in French by the Free Economic Society in St Petersburg in $1879 .^{7}$ It was rarely cited at the time. The Free Economic Society was still advertising copies for sale, for 40 copecks, in $1894{ }^{8}$ The pages were still uncut in copy I consulted in the National Library of Russia in St Petersburg in 2012. The catalogue of world libraries ("Worldcat") lists only one copy: a photocopy in the library of the University of Illinois acquired in 1994. The U.S. Department of Agriculture's National Agricultural Library in Beltsville, Maryland, does have a copy, which it acquired in $1904 .{ }^{9}$ Even more obscure seems to have been a three-page summary in German of Dokuchaev's 1883 monograph by Eduard Brückner published in 1886 in a German journal. ${ }^{10}$ It seems also to have been little cited.

${ }^{6}$ See Ototskii P.V. Iz sudeb russkogo pochvovedeniia. Pochvovedenie, 1909, no. 3. Prilozhenie, p. 14; Boulaine J.V. V. Dokouchaev et les débuts de la pédologie. Revue d'histoire des sciences, 1983, vol. 36, nos 3-4, pp. 285-306; Vtorov I. P. Soil as a museum exhibit in Russia. 13th International ERBE Symposium: Cultural Heritage in Geosciences, Mining and Metallurgy, Libraries - Archives - Museums: Proceedings, ed. Daniel Harvan. Banská Štiavnica: Slovak Mining Museum Banská Štiavnica, 2016, pp. 238-240.

7 Dokuchaev V.V. Tchérnozème (terre noire) de la Russie d'Europe: Comptes-rendus de W. Dokoutchaew. St Pétèrsbourg: Société Impériale Libre Économique, 1879.

${ }^{8}$ Anon. Reklama. Trudy vol'nogo ekonomicheskogo obshchestva, 1894, no. 5, p. 222.

${ }^{9}$ NAL Special Collections, call number Special Collections 56.33 D68T; email to author from Amy Morgan, Special Collections Librarian, April 6, 2017.

${ }^{10}$ Brückner, E. Die russische Schwarzerde. Der Naturforscher: Wochenblatt zur Verbreitung der Forschritte in den Naturwissenschaften, 1886, Dec. 25, no. 52, pp. 513-515. 
The "Exposition Universelle" in Paris in 1889 provided a better opportunity to bring the Russian soil science to international attention. Dokuchaev and his former student V.I. Vernadskii organised a soil exhibit. ${ }^{11}$ They displayed samples of the main types of soil in Russia, including chernozem, with descriptions of their profiles, explanations of their regional distribution, Dokuchaev's theory of soil formation, and his system of classification. Also on display were soil maps of Russia, diagrams, and tables of data. The texts were in French as well as Russian. In addition, there was a collection of publications by Dokuchaev and his students. They included Dokuchaev's 1883 monograph in Russian, but also the articles published in French in 1879, and a guide to the exhibit in French. ${ }^{12}$ Dokuchaev, who visited Paris during the fair, was concerned for the success of his exhibit. He was pleased to hear that he had been awarded a Gold Medal (or rather, as Vernadskii explained, the right to purchase a medal). Vernadskii and another of the Russian organisers wrote to Dokuchaev that there was some interest among French scientists. ${ }^{13}$ The French geologist Emmanuel de Margerie wrote effusively to Dokuchaev about the exhibit. ${ }^{14}$ Another French geologist, Stanislas Meunier, mentioned his work in a review of recent scientific literature in a French periodical. ${ }^{15}$ On the other hand, a lengthy French report on the fair, published in translation in a Russian periodical, referred only in passing to the soil display in a brief reference to the small Russian exhibit, but expressed far more interest in the vodka on show. ${ }^{16}$

Dokuchaev was ill-served by the administration of the Russian section at the Paris fair of 1889. They gave him little assistance and placed the soil exhibit in a poor location where it attracted little attention. ${ }^{17}$ Russian participation in the fair was unofficial and its modest agricultural display was greatly overshadowed by a far larger American exhibit organised much more effectively by the U.S. Department of Agriculture. ${ }^{18}$ Dokuchaev, who had paid for his exhibit himself, was frustrated by the lack of attention. ${ }^{19}$ The publications exhibited in Paris did, however, prompt a Belgian scientist to

${ }^{11}$ Dokuchaev V.V. Sochineniia. Vol. 8: Raboty i vystupleniya. Perepiska. Moscow; Leningrad, 1961, pp. 359-362.

${ }_{12}$ Sankt-Peterburgskii filial Arkhiva Rossiiskoi Akademii Nauk (PFA RAN). Fond 184, Dokuchaev V.V. Op. 1. D. 112. Kratkii nauchnyi obzor pochvennoi kollektsii vystavlennoi v Parizhe v 1889 g. prof. V.V. Dokuchaevym i ego uchenikami.

${ }^{13}$ Dokuchaev, Sochineniia, vol. 8, pp. 369-371, 514-516.

${ }^{14}$ PFA RAN, F. 184, Op. 2, D. 66, Marzheri, E (E. Margerie), Pis'mo k V.V. Dokuchaevu, 1889, VII, 10. Paris.

${ }_{15}$ Meunier, S. Le Trimestre scientifique. La Nouvelle Revue, 1889, vol. 61, pp. 121-139.

${ }^{16}$ Dedlov V.L. Parizh i ego vystavka. Pis'ma chetvertoe i pyatoe. Knizhki nedeli, 1889, September, p. 153.

${ }^{17}$ Efron A.A. Torzhestvuyushchaya Frantsiya. St Peterburg, 1890, pp. 147-148.

${ }^{18}$ Bogdanov S.M. Zemledelie na Parizhskoi vsemirnoi vystavke 1889 goda. Sel'skoe khoziaistvo i lesovodstvo, 1889, vol. 162, pp. 45, 66-67, 75-78.

${ }^{19}$ Efron Torzhestvuiushchaia Frantsiia, pp. 147-148. 
read a paper in French summarizing Dokuchaev's work to a Belgian scientific society on April 15, 1890. The paper was published in the society's bulletin, thus providing another summary of the Russian work in a western European language. ${ }^{20}$

In the United States, Dokuchaev's former student, A.N. Krasnov, presented a paper on "The 'Black Earth' of the steppes of southern Russia" to the $5^{\text {th }}$ International Geological Congress in Washington, DC, on August 25, 1891. Krasnov summarized the studies of the black earth by Dokuchaev and his colleagues. He explained their focus on the wider environmental conditions in which the soil had formed. ${ }^{21} \mathrm{Krasnov}$ wrote to Dokuchaev a few days after the Congress that his paper had aroused great interest among the American scientists. ${ }^{22}$ One of the scientists, Hilgard, wrote that he was "greatly interested in Professor Krasnof's paper, as I have studied the American 'black-prairie soils' ... and, on the whole, I agree entirely with him in his conclusions as to the conditions under which such soils may be formed." Hilgard indicated that he gave more emphasis to the underlying geology, but agreed that the "other concurrent conditions" (i.e. Dokuchaev's soil-forming factors) were also necessary. ${ }^{23}$

The Russian government devoted significant resources to promoting Russian agriculture, industry, mining, transportation, and culture at the World's Columbian Exposition held in Chicago in $1893 .{ }^{24}$ The government published a five-volume work entitled The Industries of Russia, including a volume on "Agriculture and Forestry". 25 The second chapter, on soil, was written by P.A. Kostychev. He wrote that "European Russia" was divided into two halves, the "region of the Chernoziom or "black earth"” in the south-east and the "non-Chernoziom lands" in the north and north-west, and that this "difference in soils ... corresponds almost exactly" to the division between steppe and woodland. His account emphasized the underlying geology, the chemical composition, and physical properties, i.e. texture, of soils ahead of climate. This reflected a disagreement between Kostychev and Dokuchaev on the relative importance of climate in soil formation. ${ }^{26}$ Russian genetic soil science was displayed more effec-

${ }^{20}$ Dokoutchaieff V.V. Notes sur l'etude scientifique du sol en Russie au point de vue de l'agronomie et de la cartographie agricole. Bulletin de la Société belge de géologie, de paléontologie et d'hydrologie, 1890, vol. 4, pp. 113-116.

${ }^{21}$ Krassnof A.N. The 'Black earth' of the steppes of Southern Russia. Bulletin of the Geological Society of America, 1892, vol. 3, pp. 68-81 (quotations from p. 73).

22 Dokuchaev Sochineniia, vol. 8, p. 499.

${ }^{23}$ Hilgard's comments were reporded in Krassnof. The 'Black earth, p. 80.

${ }^{24}$ Sokolov S.M. Rossiia na vsemirnoi vystavke v Chikago v 1893 g. Amerikanskii ezhegodnik, 1984, pp. 152-164.

${ }^{25}$ Crawford J. (ed.) The Industries of Russia, vol. 3, Agriculture and Forestry. St Peterburg, 1893.

${ }^{26}$ Crawford. The Industries of Russia, vol. 3, Agriculture and Forestry, pp. 18-41; Rossiiskii Gosudarstvennyi istoricheskii arkhiv. (RGIA), F. 399, Op. 1, D. 238, L. 26; Kostychev P.A. Po voprosu o proiskhozhdenii chernozema. Sel'skoe khoziaistvo i lesovodstvo, 1884, vol. 147, pp. 259282. 
tively in the soil exhibit, which was prepared by Dokuchaev and Sibirtsev. It included a collection of soil "monoliths" revealing the profiles and different horizons in soils from around the Russian Empire. They were accompanied by maps, charts, diagrams, and publications. ${ }^{27}$ Two publications on Russian soil science in English were prepared specially for the exhibit. ${ }^{28}$

The soil exhibit at the Chicago fair did little to facilitate the dissemination of the Russian scientific innovation in the United States. There was little attention to it in American press coverage of the fair. The Chicago Tribune, for example, described the Russian exhibit as "one of features of the fair", and praised the furs, lacquer boxes, and "embroideries, weapons, articles of dress and household ornamentation". It noted that the agricultural exhibit was "one of the most important and best arranged", but did not mention the soils. ${ }^{29}$ An illustrated Book of the Fair, published in 1894, described the Russian agricultural exhibit, but not the soils. ${ }^{30}$

Even the Russian official report on its section at the Chicago fair missed out the Russian soil exhibit. ${ }^{31}$ American soil scientists seem not to have taken great interest in the Russian soil exhibit at Chicago. American historians of soil science have argued that the Russian soil exhibit in Chicago had little impact on the science in the United States. ${ }^{32}$ There was an exception. Charles F. Vanderford's study of "The Soils of Tennessee" (1897) contained illustrations of men collecting soil profiles and analyzing them in line with the approach of the Russian genetic soil scientists. ${ }^{33}$ It seems

${ }^{27}$ Anon. World's Columbian Exposition 1893 Chicago: Catalogue of the Russian Section. St Peterburg, 1893, p. 103. I tried to find out if the soil monoliths still existed, but was disappointed to learn that they were returned to St Petersburg from Chicago and stored in a basement, where they were destroyed by a flood when the River Neva broke its banks. Email to the author from Dr Ivan Vtorov, June 16, 2016.

${ }^{28}$ Dokoutschaieff W.W. and Sibirtzeff N.M. Short scientific review of prof. Dokoutschaeff's and his pupil's collection of soils, exposed in Chicago in the year 1893. St Peterburg, 1893; Dokuchaev V.V. The Russian steppes. Study of the soil in Russia, its past and present. St Peterburg, 1893. (The variant spellings of Dokuchaev's names are taken directly from the originals.)

${ }^{29}$ Anon. Czar Land Treasure: Russia's Display One of Features of the Fair. Chicago Tribune, 1893, July 24.

${ }^{30}$ Bancroft H.H. The Book of the Fair: An Historical and Descriptive Presentation of the World's Science, Art and Industry, As Viewed through the Columbian Exposition at Chicago in 1893. New York, 1894, pp. 209, 341, 372-373, 383.

${ }^{31}$ Glukhovskii P.I. Otchet general'nogo kommissara Russkogo otdela Vsemirnoi kolumbovoi vystavki v Chikago. St Peterburg, 1895.

${ }^{32}$ Selcer P. Patterns of Science: Developing Knowledge for a World Community at Unesco: Ph.D. Dissertation. University of Pennsylvannia, 2011, p. 364; Simonson R.W. Early Teaching in USA of Dokuchaiev Factors of Soil Formation. Soil Science Society of America Journal, 1997, vol. 61, p. 12.

${ }^{33}$ Vanderford C. F. The Soils of Tennessee. Tennessee Agricultural Experiment Station Bulletin, 1897, vol. 10, no. 3, pp. ii-iii, 33, 34, 41, 49, and passim. 
that Vanderford got the ideas from the Russian soil exhibit at Chicago. ${ }^{34}$ But, Vanderford's work received little attention in the United States. ${ }^{35}$

A further opportunity to promote Russian soil science on an international stage came at the Paris world's fair in 1900. Russia was officially represented and a enlarged soil exhibit was part of a much bigger and better organized Russian presence than in 1889. Ototskii was entrusted by the Ministry of Agriculture with preparing an exhibit to familiarize foreigners with the principles of the innovative Russian genetic soil science. The exhibit, as at previous world's fairs, included soil samples, diagrams, tables, maps, this time including a map of soil zones around the northern hemisphere, and publications. ${ }^{36}$ Specially prepared for the exhibit were substantial guides to the display and to Dokuchaev's theories in French to facilitate a larger, international readership. ${ }^{37}$ The exhibit and the Russian soil science it presented were well received by French scientists, including Margerie, who published articles about it in French scientific periodicals. ${ }^{38}$

Over the following years, Russian soil science became better known in Europe and received a receptive audience among some European soil scientists. Soil scientists in several European countries were seeking to develop common systems for conceptualizing, classifying, and mapping soils. They began to hold conferences to build an international discipline of soil science. This created a further opportunity for Russian soil scientists to disseminate their work to an international audience. The first conference of what was termed "agrogeology" was held in Budapest in the AustroHungarian Empire in April 1909. Six countries were represented, including Germany and the Russian Empire. ${ }^{39}$ Glinka presented a paper on soil zones and soil types in European and Asiatic Russia, which was illustrated by a collection of soil samples and a map to show their geographical distribution. He reported back to his Russian colleagues that their works were cited with approval by several delegates. The conference was followed by excursions, one of which enabled participants to see cherno-

${ }^{34}$ Gardner D.R. The National Cooperative Soil Survey of the United States. Washington D.C, 1998, p. 18.

${ }^{35}$ Kellogg C.E. Soil and Society. Soils and Men. Yearbook of Agriculture, 1938, p. 883.

${ }^{36}$ Anon. Khronika. Pochvovedenie, 1909, no. 1, pp. 68-69; Anon. Khronika. Pochvovedenie. 1900, no. 2, pp. 154-155; RGIA, F. 91, Op. 2, 1899, D. 205.

${ }^{37}$ Dokuchaev V.V. Collection pedologique du professeur B. Dokoutshcaeff. Zones verticales des sols. Zones agricoles. Sols du Caucase St Peterburg, 1900; Ototzky P. Guide scientifique sommaire de la section pédologique russe à l'Exposition Universelle de Paris. St Peterburg: Ministère de l'Agriculture et des Domaines, 1900.

${ }^{38}$ Margerie E. de and Raveneau L. La cartographie a l'Exposition universelle de 1900. Annales de geographie, 1900, vol. 9, pp. 402-407; Carmena d'Almeida P. La carte des sols de la Russie, publiée par le Departement de l'agriculture. Annales de geographie, 1904, vol. 13, pp. 270-275.

${ }^{39}$ Michéli E. and Fuchs M. Bridging the Centuries: 1909-2009. Centennial meetings on the 100th anniversary of the 1st International Conference of Agrogeology. Agrokémia és Talajtan, 2010, vol. 59, no. 1, pp. 195-202. 
zems and other soils on the Hungarian plain. ${ }^{40}$ A second agrogeological conference was held in Stockholm, Sweden, in 1910. The conference, which was attended by Glinka, laid the groundwork for further cooperation towards creating common methodologies and systems for classifying and mapping soils. A third "agrogeological" conference planned for St Petersburg in 1914 was not held because of the outbreak of the First World War. ${ }^{41}$ The contacts Glinka made at the conferences, in particular with German scientist Hermann Stremme, were important in the further dissemination of Russian soil science as Glinka and Stremme agreed to collaborate on the book Glinka wrote in German. ${ }^{42}$

The dissemination and acceptance of Russian soil science in the United States was slower than in Europe, in spite of the increasing availability of information about it which was accessible to American scientists. Russian soil science received a little more publicity in the United States at and very end of the century. In 1899-1900 the journal Experiment Station Record published two short notices about work on Russian soil science, including the first issue of the journal Pochvovedenie. ${ }^{43}$ The following year, it published a translation of abridged versions of two articles by Sibirtsev under the title "Russian soil investigations". The articles explained Dokuchaev's pioneering work, the zonal system of soil classification, the theory of soil formation, and presented detailed analyses, including the chemical and mechanical composition, of different types of soils, together with an explanation of the different soil "horizons" (this word was used in the translation). Sibirtsev's article cited Hilgard's work and indicated some similarities between it and the Russian work. ${ }^{44}$ The editorial notes at the start of the issue containing Sibirtsev's article summarized the nature of the Russian soil science, how it differed from other work on soils, and pointed to its applicability to the western part of the United States (which included the Great Plains):

[Dokouchayev] has founded a new school of soil investigation, the fundamental idea of which is the conception of the soil as an independent natural body. With the collaboration of Sibirtzev, this idea has been utilized in the elaboration of a so-called genetic or natural classification of soils, which, in the study of soil formations, re-

${ }^{40}$ Glinka K.D. Pervaia agrogeologicheskaia konferentsiia v Budapeshte. Pochvovedenie, 1909, no. 2, pp. 125-140.

${ }^{41}$ Anon. History of the Organization of the International Society of Soil Science; Iarilov A.A. Po povodu vtorogo mezhdunarodnogo agrogeologicheskogo s"ezda v Stockgol'me. Pochvovedenie, 1910, no. 4, pp. 367-383.

${ }^{42}$ Arend. Russian Science in Translation.

${ }^{43}$ Ototskii P.V. Science of Soils. Experiment Station Record, 1899-1900, vol. 11, pp. 434; Sovietov A. and Adamov N. Contributions to the Study of Russian Soils. Experiment Station Record 1899-1900, vol. 11, p. 623.

${ }^{44}$ Anon. Russian Soil Investigations Experiment Station Record. 1900-1901, vol. 12, pp. 704 712, 807-818. See also Sibirtzew V.N. (sic) Étude des sols de la Russie. Avec une carte et deux planches. Congrès géologique Internationale compte rendu de la VII session, vol. 2. St Petersbourg, 1899, pp.74-125. 
quires a differentiation between parent rock species and the cultivated horizon. His classification differs fundamentally from the petrographic [i.e. geological] and physico-chemical classifications commonly followed by investigators who have dealt with soils which have been profoundly modified under culture, rather than with those in a largely virgin condition, as in Russia and in the western United States. ${ }^{45}$

The items in Experiment Station Record were translated from Russian by Peter Fireman, who taught chemistry at George Washington University in Washington, DC, from 1893 until 1901. Fireman was born into a Jewish family in Lipovets, in today's Ukraine, then part of the Russian Empire. He was educated at universities in Odessa, and then in Germany and Switzerland, before moving to the United States in $1882 .{ }^{46}$ Jewish émigrés such as Fireman were among the few people in the United States at this time who had both the language skills and scientific training necessary to disseminate the findings of Russian scientists.

Fireman's translation of Sibirtsev's essays was only the second article (after Krasnov's) on Russian soil science published in English in an American scientific periodical. Simonson, writing in the 1980s, noted: "Looking at the translation now, I think it was good. Yet it made little or no impression on American soil scientists." This was harsh. It was cited by George Coffey, a scientist at the U.S. Bureau of Soils, who cited it, together with Sibirtsev's paper in French to the Geological Congress held in St. Petersburg in 1897, in his doctoral dissertation, which the Bureau published as "A Study of the Soils of the United States" in $1912 .{ }^{48}$ Coffey, whose academic background was in geology and chemistry, started working at the Bureau in 1900. While working at the Bureau he realised the need for a better system for classifying soils than the existing American system that was based largely on soil texture and geological origins. This prompted him to study for higher degrees at George Washington University. ${ }^{49}$ In his dissertation Coffey noted that "Dokouchayev" had "founded a new school of soil investigation". He presented Sibirtsev's zonal system of classification, and explained "the Russians make their primary classification upon the origin of the soil - not so much the geological as the climatic and organic origin."

45 Anon. Editorial Notes. Experiment Station Record. 1900-1901, vol. 12, p. 701.

${ }^{46}$ Anon. Fireman P. In National Cyclopedia of American Biography, vol. 52. New York, 1970, pp. 270-2.

${ }^{47}$ Simonson R.W. Historical highlights of soil survey and soil classification with emphasis on the United States, 1899-1970. Wageningen, 1989, p. 47.

${ }^{48}$ Coffey G.N. A Study of the Soils of the United States. U.S. Department of Agriculture, Bureau of Soils, Bulletin no. 85. Washington, DC, 1912, pp. 32-33; Coffey G.N. The Development of Soil Survey Work in the United States with a Brief Reference to Foreign Countries. Proceedings of the American Society of Agronomists, 1911, vol. 3, pp. 127-129.

${ }^{49}$ Brevik E.C. George Nelson Coffey, Early American Pedologist. Soil Science Society of America Journal, 1999, vol. 63, no. 6, pp. 1485-1493; Helms D. Early Leaders of the Soil Survey. Helms D. (ed al eds.) Profiles in the History of the U.S. Soil Survey. Ames, IO, 2002, pp. 35-39. 
Coffey contrasted the sophisticated and multi-faceted Russian system for classifying soils with those of France, Germany, and Japan, which were based on geology. He also contrasted the Russian system with that of the U.S. Bureau of Soils, which he described as "largely physical", i.e. it was based on soil texture and the underlying geology. Coffey also cited with approval the work of Hilgard, which had a broader concept of soils, and also listed Vanderford's work in his bibliography. ${ }^{50}$

Coffey drew on the Russian work in the body of his dissertation, for example, in defining soil as "an independent natural body... differing essentially from the rock which underlies it". He emphasized the character of the parent material as well as "soil forming agencies". Among the latter, he included the parent rock, moisture, temperature, climate, and hinted at the importance of topography and "age", i.e. time. But, in contrast to the Russians, he did not include vegetation as a "soil forming agency". Also in contrast to the Russian soil scientists, Coffey did not analyze horizons or layers in soil profiles, but did refer occasionally to differences between "soil" and "subsoil" ${ }^{51}$ Coffey devised a classification system which he acknowledged was "preliminary" and needed far more information to finalize it. ${ }^{52}$ His hopes of replacing the existing system of soil classification employed the U.S. Bureau of Soils with a new one based on Russian soil science did not come to pass. Such was the opposition to change by the chief of the Bureau, Milton Whitney, that Coffey resigned in 1911 to take up a post in Ohio. ${ }^{53}$

There were two American scientists, who were specialists in other fields, who were more receptive to the Russian soil science. They were Niels Hansen and Mark Carleton. Both were specialists on agricultural crops and both visited the Russian Empire as plant explorers looking for new crops to grow in the United States. Hansen visited the Russian soil exhibit at the fair in Chicago and met the Russian soil scientist V. R. Vil'iams $\backslash$ Williams (his father, Robert, was American), who was a member of the Russian delegation. Four decades later, while visiting the Soviet Union, Hansen recalled meeting Williams in Chicago and wrote: "The science work in soils [in the Soviet Union] is considered superior to that anywhere in the world. ${ }^{, 54}$ Carleton was interested in the similarities between the soils and climate of the Great Plains and steppes, which prompted him to visit the steppes to collect varieties of grain to grow

${ }^{50}$ Coffey, 1912 cited Hilgard on, e.g., pp. 6, 14, 30, 31, 39. Vanderford's work is listed on p. 113.

${ }^{51}$ Coffey, 1912, pp. 7, 8, 13-23, 31, 35-37, 40-44 and passim. The map is at the end of the volume.

${ }^{52}$ Coffey, 1912, pp. 27-29, 34; Gardner, 1998, pp. 49-50.

${ }^{53}$ Helms, 2002, pp. 39-40.

${ }^{54}$ South Dakota State University Archives and Special Collections. Hilton M. Briggs Library, Brookings, South Dakota, UA 53.4, N. E. Hansen papers, Series 2. Helen Hansen Loen Collection. Box 3. Folder 93. Niels Hansen to his father, June 8, 1893 [trans from Danish]; Box 4, Folder 174, p. 244. 
in the United States. Before he travelled to Russia, Carleton ordered samples of "wheat soils" to be sent to him from Russia to Kansas in 1895. He sent them on to the Bureau of Soils in Washington, DC, for analysis. ${ }^{55}$ Carleton was interested not just in the soils from the steppes, but in the theories of Russian soil scientists. In 1914 he wrote about the attention "Russian investigators" gave to the vegetation and "factors such as temperature and moisture" in "black soil formation". He noted that the Russian work, on what he termed "geo-botany", by Dokuchaev, Kostychev, Krasnov, and others "has already reached several hundred volumes" and that: "It would be of great benefit to American students to have at least abstracts of these publications put into English." 56

The positive response to Russian soil science by Hansen and Carleton, who were specialists in another branch of agricultural sciences, suggests that it may have been the innovative nature of the Russian work, which contradicted prevailing orthodoxies among American soil scientists, that inhibited its reception among soil scientists, and Whitney in particular, in the United States. This can be demonstrated by the attitude of Hilgard, who had been so interested in Krasnov's paper in 1891, to the work of his Russian counterparts. Hilgard's work was also at variance with the prevailing ideas among American soil scientists, and in some regards it resembled the Russian work. Hilgard did not visit Russia and could not read Russian, but was sufficiently interested to make an effort to find out more about Russian soil science. He corresponded with several Russian scientists from the 1870s. The interest was mutual. Russian scientists made contact with Hilgard. His first Russian correspondent was the geographer and climatologist A.I. Voeikov, who visited North America in the 1870s. They wrote, in English, about mutual interests in studying the soils of Russia and North America, and exchanged publications. ${ }^{57}$ A recurring theme in Hilgard's letters to Russian scientists was his desire to increase his knowledge of Russian soil science, but regret that he could not read Russian. Voeikov suggested Hilgard wrote to Dokuchaev:

As to Prof. Dokutschaef, Voeikov wrote to Hilgard on January 6/18 1892, his address is Novaja Alexandria, gouv. Ljublin,... You may write the address in German and the letter in French. German is less familiar to him, but can certainly find people to translate your communication. Perhaps you would best do so: write a short letter in French and ... questions in German, and send also copies of your works, especially

${ }^{55}$ National Archives and Records Administration, College Park, MD (NARA CP). Record Group 54. Finding Aid A1. Entry 58 Division of Vegetable Pathology and Physiology: Correspondence of M.A. Carleton, 1891-1900, Folder: M.A. Carleton - 1895. Carleton to B.T. Galloway, November 1, 1895, Carleton to Galloway, November 9, 1895.

${ }^{56}$ Carleton M.A. The small grains. New York, 1916, pp. 235-237.

57 Bancroft Library, University of California, Berkeley. The Hilgard family papers. BANC MSS C-B 972 (Hilgard Papers). Hilgard E. W.: Incoming Letters, Box 23. File: Voeikov, Aleksandr Ivanovich. 
what is published in French or German. I am sure he will be very glad to communicate with you. ${ }^{58}$

Sadly for historians of soil science, it seems the two pioneers - one Russian, one American - did not correspond with each other. ${ }^{59}$ Voeikov encouraged Hilgard to visit Russia when he was in Europe in 1892, advising him that he would not suffer from the Russian climate if he brought the right clothing. If he came, Voeikov offered to help him with translations of Russian studies. He also explained that, since many Russian specialists spoke German (Hilgard's mother tongue), he would be able to speak with them. Voeikov was disappointed when Hilgard did not visit, remarking: "You are spoiled by the climate of California". ${ }^{0}$ This did not prevent Hilgard from reading about Dokuchaev's work in western European languages. On May 24, 1894, he wrote to Vilbouchevitch, who was then about to visit St Petersburg: "I am glad to know that you will be at the headquarters of the soil work of Russia ... I have been looking over lately all I have on Dokutshaieff's work, and find it as closely parallel to my own as I could wish," but pointed out that he disagreed on some points concerning the analysis of organic matter. ${ }^{61}$

Voeikov continued to encourage Hilgard to learn more about Russian soil science. In the summer of 1902 he wrote: "It is much to be regretted that you are unable, in California, to use Russian books, for as to the study of soils we are further advanced than any country in Europe. You should study Russian on the Pacific coast..." ${ }^{62}$ Hilgard continued in his desire to learn more about the Russian work. In January 1908, he wrote to P.V. Ototskii, the editor of Pochvovedenie. He noted that he had persuaded his university library to subscribe to the journal, but that it had dropped it ("without my knowledge"), presumably because "so few here understand the Russian language". He wrote that he was trying to get the subscription renewed, and asked Ototskii if:

both for the proper appreciation of the excellent work being done in Russia in this line, ..., it should be worth your while, ... to have ... abstracts [of articles] made, say in French or German, so as to enable us to correspond with the authors...

${ }^{58}$ Hilgard Papers Hilgard E.W.: Incoming Letters, Box 23. File: Voeikov, Aleksandr Ivanovich, Jan [?] 6/18, 1892, Voeikov to Hilgard.

${ }^{59}$ There is no correspondence between them in Hilgard's Papers: Hilgard E.W.: Incoming Letters, Box 8 (Coo-E Misc, incl D Misc); Hilgard E.W.: Outgoing Letters, Box 1, 1848-1883, Box 2, 1884-1904. There is none in Dokuchaev's papers, PFA RAN, F. 184, Dokuchaev V.V., nor in his published correspondence. Dokuchaev, Sochineniia, vol. 8.

${ }^{60}$ Hilgard Papers. Hilgard E.W.: Incoming Letters, Box 23. File: Voeikov, Aleksandr Ivanovich, Dec 18/30 1892, Voeikov to Hilgard; October 22/November 3 [1893?], Voeikov to Hilgard.

${ }^{61}$ Hilgard Papers. Hilgard E.W.: Outgoing Letters, Letterpress copy books, vol. 20, Feb. 1894 Oct. 1896, pp. 57-58, May 24, 1894, Hilgard to Vilbouchevitch.

${ }^{62}$ Hilgard Papers. Hilgard E.W.: Incoming Letters, Box 23, File: Voeikov, Aleksandr Ivanovich, June 22/July 5, 1902, Voeikov to Hilgard. 
Hilgard intended to read the abstracts and then arrange full translations of articles he was interested in by a Russian acquaintance. ${ }^{63}$ He repeated the request to another Russian soil scientist, N.M. Tulaikov. Ototskii's initial response was that it was a question of resources and that he, as editor, was already overburdened. ${ }^{64}$ Nevertheless, Hilgard's suggestion was taken up. In May 1911, in a letter to Ototskii, Hilgard expressed his "gratification at the adoption of the policy of giving summary translations of the Russian texts in your journal". He added that it would increase appreciation of "the fine work that is being done in Russia..." Hilgard's letter implied a contrast between the quality of the Russian work and

the frequent publications of the Bureau of Soils at Washington... [which] usually contain so much ill digested matter and unwarranted conclusions - owing to the wholly one-sided point of view of the Chief, Professor Whitney, that it would take a great deal of time and space to controver them all. ${ }^{65}$

Hilgard sometimes cited Russian studies (in translation) in his publications, ${ }^{66}$ and was pleased to learn that his work was known and appreciated in Russia. In March 1908, for example, he wrote to his sisters that he had been sent positive reviews of his book on soils in Russia by Voeikov and Tulaikov. ${ }^{67}$

Tulaikov spent a year in the United States in 1908-9, much of it in Berkeley, California, to study American work on soils. He was especially interested in Hilgard's work. At the start of his visit, Tulaikov noted with some dismay that his American counterparts did not know about Russian work, although some were interested. ${ }^{68}$ Like Krasnov's visit a decade and half earlier, Tulaikov's presence provided an opportunity for American scientists to learn more about the Russian soil science. While some, like Hilgard, were interested, his visit also revealed the divisions among American soil scientists over methodology and concepts of soils that would hinder attempts to change it. While he was in Berkeley, Tulaikov wrote an article on "The Genetic Classification of Soils" in English, which was published in a British journal, and attracted little attention in the United States. ${ }^{69}$ He visited the Bureau of Soils in Washington,

${ }^{63}$ Hilgard Papers. Hilgard E.W.: Outgoing Letters, Letterpress copy books, vol. 26, June $1907-$ July 1910, pp. 124-125, January 27, 1908, Hilgard to Dr. P. Ototzky, St Petersburg, Russia.

${ }^{64}$ Hilgard Papers. Hilgard E.W.: Outgoing Letters, Letterpress copy books, vol. 26, June $1907-$ July 1910, pp. 120-123, January 28, 1908, Hilgard to Toulaikoff; Tulaikov N.M. Pochvennye issledovaniia v Soedinennykh Shtatakh. Pochvovedenie, 1908, no. 4, pp. 321-322.

${ }^{65}$ Hilgard Papers. Hilgard E.W.: Outgoing Letters, Box 3, May 11, 1911, Hilgard to Professor P. Ototzky [Ototskii].

${ }^{66}$ Hilgard E.W. Soils: their formation, properties, composition, and relations to climate and plant growth in the humid and arid regions. New York and London, 1906, pp. 130, 265.

${ }^{67}$ Hilgard Papers. Hilgard E.W.: Outgoing Letters, Box 3 1905-1915, March 12, 1908, Hilgard to Therese; March 27, 1908, Hilgard to Rosa.

${ }^{68}$ Tulaikov, 1908, pp. 321-322.

${ }^{69}$ Tulaïkoff N.M. The Genetic Classification of Soils. The Journal of Agricultural Science, 1908, no. 3, pp. 80-85; Simonson, 1989, p. 48. 
DC, and met Milton Whitney, who acquainted him with the work of the U.S. soil survey. However, he was critical of the American methods, recognizing them as inferior to those devised by Russian soil scientists. ${ }^{70}$

\section{Conclusion}

Thus by 1914, when Glinka's book on Russian soil science was published in German, there was already quite a lot of information about the Russian innovation available in western European languages. Russian soil scientists had endeavoured to publicise their new science through publications in foreign languages, had prepared exhibits and pamphlets for international exhibitions, presented papers at international conferences, and corresponded with their counterparts in different countries. Their work found a more receptive audience among some European scientists, to the extent that Glinka collaborated with a German scientist, Stremme, in preparing his book. The acceptance of Russian soil science was slower in the United States. This was in spite of the availability of information in English, Russian exhibits at American fairs, visits by Russian soil scientists who gave papers at American conferences, and correspondence between Russian and some American scientists. Resistance to the new ideas on soils from Russia was stronger in the United States. This was a result of opposition from the chief of the U.S. Bureau of Soils, Whitney, who saw the Russian science as a threat to his position and work, which was based on an older physical and geological conception of soils. Later, recognition of the value of Russian soil science for studying American soils, by some American scientists, in particular by the head of the U.S. Soil Survey Curtis Marbut, and the death of Whitney in 1927 finally allowed the wider acceptance of Russian soil science in the United States. ${ }^{71}$

\section{References}

1. Anon. Khronika [The Chronicle]. Pochvovedenie [Soil Science], 1909, no. 1, pp. 68-69.

2. Anon. Khronika [The Chronicle]. Pochvovedenie [Soil Science], 1900, no. 2, pp. 154-155.

3. Anon. [Reklama]. Trudy vol'nogo ekonomicheskogo obshchestva [The works of the Free Economic Society], 1894, no. 5, p. 222.

4. Bogdanov S.M. Zemledelie na Parizhskoi vsemirnoi vystavke 1889 goda [Agriculture at the Paris World Exhibition in 1889]. Sel'skoe khoziaistvo i lesovodstvo [Agriculture and Forestry], 1889, vol. 162, pp. 45-85.

5. Vtorov I.P. Pervoe vospriiatie idei V.V. Dokuchaeva mezhdunarodnym nauchnym soobshchestvom. Unpublished paper presented to Mezhdunarodnyi nauchnyi seminar "Nauchnoe nasledie

${ }^{70}$ Tulaikov, 1908, pp. 293-322; Tulaikov N.M. Ocherki po sel'skomu khozyaistvu v Soedinennykh Shtatakh. Moscow, 1912, pp. 118-22; Tulaikov N.M. Pochvennoe Biuro pri Departamente Zemledeliia Soedinennykh Shtatov. Pochvovedenie, 1909, no. 1, pp. 17-33.

${ }^{71}$ Brevik E.C., Fenton T.E., Homburg J.A. Historical highlights in American soil science Prehistory to the 1970s. Catena, 2016, vol. 146, pp. 111-127. 
V.V. Dokuchaeva: traditsii i razvitie idei" [The first perception of V. V. Dokuchaev's ideas by the international scientific community. Unpublished paper presented at the International scientific seminar on "Scientific heritage of V. V. Dokuchaev: the traditions and development of ideas»]. Moscow, 30-31 May 2016. (In Russian)

6. Glukhovskii P. I. Otchet general'nogo kommissara Russkogo otdela Vsemirnoi kolumbovoi vystavki $v$ Chikago [Report of the Commissioner-General of the Russian section of the world Columbian exhibition in Chicago]. St Peterburg: Kirshbaum, 1895. (In Russian)

7. Dedlov V.L. Parizh i ego vystavka. Pis'ma chetvertoe i pyatoe [Paris and its exhibition. Letters fourth and fifth]. Knizhki nedeli [Books of the week], 1889, September, pp. 99-158.

8. Dobrovol'skii G.V. Lektsii po istorii pochvovedeniia [Lectures on the history of soil science]. Moscow: MGU, 2010. 232 p. (In Russian)

9. Dokuchaev V.V. Russkii chernozem [Russian black earth]. St Peterburg: Imperatorskoe Vol'noe Ekonomicheskoe Obshchestvo, 1883. 384 p. (In Russian)

10. Dokuchaev V.V. Sochineniia. Vol. 8 Raboty i vystupleniya. Perepiska [Compositions. Works and presentations]. Moscow; Leningrad: AN SSSR, 1961. 556 p. (In Russian)

11. Efron A.A. Torzhestvuyushchaya Frantsiya [Triumphant France]. St Peterburg, 1890. 31 p. (In Russian)

12. Glinka K.D. Pervaia agrogeologicheskaia konferentsiia $v$ Budapeshte [The first archaeological conference in Budapest]. Pochvovedenie [Pedology], 1909, no. 2, pp. 125-140. (In Russian)

13. Kostychev P. A. Po voprosu o proiskhozhdenii chernozema [On the question of the origin of the black soil]. Sel'skoe khoziaistvo i lesovodstvo [Agriculture and forestry], 1884, vol. 147, pp. 259-282. (In Russian)

14. Krupenikov I.A. Istoriia pochvovedeniia: ot vremeni ego zarozhdeniia do nashikh dnei [History of soil science: from its inception to the present day]. Moscow: Nauka, 1981. 328 p. (In Russian)

15. Ototskii P. V. Iz sudeb russkogo pochvovedeniia [From the fates of Russian soil science]. Pochvovedenie [Soil science], 1909, no. 3, Prilozhenie, pp. 1-25. (In Russian)

16. Sokolov S. M. Rossiia na vsemirnoi vystavke v Chikago v 1893 g. [Russia at the world exhibition in Chicago in 1893]. Amerikanskii ezhegodnik [ American Yearbook], 1984, pp. 152-164. (In Russian)

17. Tulaikov N.M. Ocherki po sel'skomu khozyaistvu v Soedinennykh Shtatakh [Essays on agriculture in the United States]. Moscow, 1912. (In Russian)

18. Tulaikov N.M. Pochvennoe Biuro pri Departamente Zemledeliia Soedinennykh Shtatov [Soil Bureau of the United States Department of agriculture]. Pochvovedenie [Soil science], 1909, no. 1, pp. 17-33. (In Russian)

19. Tulaikov N.M. Pochvennye issledovaniia v Soedinennykh Shtatakh [Soil surveys in the United States]. Pochvovedenie [Soil science], 1908, no. 4, pp. 293-322. (In Russian)

20. Anon. Czar Land Treasure: Russia's Display One of Features of the Fair. Chicago Tribune, July 24, 1893.

21. Anon. Editorial Notes. Experiment Station Record, 1900-1901, vol. 12, p. 701.

22. Anon. Fireman P. In National Cyclopedia of American Biography, vol. 52. New York: James T. White \& Co., 1970, pp. 270-272.

23. Anon. History of the Organization of the International Society of Soil Science. Soil Science, 1928 , vol. 25 , no. 1 , pp. 3-4

24. Anon. World's Columbian Exposition 1893 Chicago: Catalogue of the Russian Section. Spb: Imperial Russian Commission, Ministry of Finance, 1893. 572 p.

25. Arend J. Russlands Bodenkunde in der Welt. Eine ost-westliche Transfergeschichte 18801945. Göttingen, 2017, p. 314.

26. Arend J. Russian Science in Translation: How pochvovedenie was brought to the West, c. 1875-1945. Kritika: Explorations in Russian and Eurasian History, 2017. (forthcoming). 
27. Bancroft H.H. The Book of the Fair: An Historical and Descriptive Presentation of the World's Science, Art and Industry, As Viewed through the Columbian Exposition at Chicago in 1893. New York: Bounty, 1894

28. Boulaine J. V.V. Dokouchaev et les débuts de la pédologie. Revue d'histoire des sciences, 1983, vol. 36, no. 3-4, pp. 285-306.

29. Brevik E.C. George Nelson Coffey, Early American Pedologist. Soil Science Society of America Journal, 1999, vol. 63, no. 6, pp. 1485-1493.

30. Brevik E.C., Fenton T.E., Homburg J.A. Historical highlights in American soil science Prehistory to the 1970s. Catena, 2016, vol. 146, pp. 111-127.

31. Brückner E. Die russische Schwarzerde. Der Naturforscher: Wochenblatt zur Verbreitung der Forschritte in den Naturwissenschaften, 1886, Dec. 25, no. 52, pp. 513-15.

32. Carleton M.A. The small grains. New York: Macmillan, 1916.

33. Carmena d'Almeida, P. La carte des sols de la Russie, publiée par le Departement de l'agriculture. Annales de geographie, 1904, vol. 13, pp. 270-275.

34. Coffey G.N. A Study of the Soils of the United States. U.S. Department of Agriculture, Bureau of Soils, Bulletin no. 85. Washington, DC, 1912. 114 p.

35. Coffey G.N. The Development of Soil Survey Work in the United States with a Brief Reference to Foreign Countries. Proceedings of the American Society of Agronomists, 1911, vol. 3, pp. 115-29.

36. Crawford J. (ed.) The Industries of Russia, vol. 3, Agriculture and Forestry. St Peterburg: The Department of Agriculture Ministry of Crown Domains, 1893.

37. Dokuchaev V.V. Collection pedologique du professeur B. Dokoutshcaeff. Zones verticales des sols. Zones agricoles. Sols du Caucase. St Peterburg: Ministry of Finance, 1900.

38. Dokoutchaieff V.V. Notes sur l'etude scientifique du sol en Russie au point de vue de l'agronomie et de la cartographie agricole. Bulletin de la Société belge de géologie, de paléontologie et d'hydrologie, 1890, vol. 4, pp. 113-116.

39. Dokuchaev V.V. Tchérnozème (terre noire) de la Russie d'Europe: Comptes-rendus de W. Dokoutchaew. St-Pétèrsbourg: Société Impériale Libre Économique, 1879. 66 p.

40. Dokoutschaieff W.W. and Sibirtzeff N.M. Short scientific review of prof. Dokoutschaeff's and his pupil's collection of soils, exposed in Chicago in the year 1893. St Peterburg: Evdokimov, 1893

41. Dokuchaev V.V. The Russian steppes. Study of the soil in Russia, its past and present. St Peterburg: Department of Agriculture, Ministry of Crown Domains, 1893.

42. Gardner D.R. The National Cooperative Soil Survey of the United States. Washington, D.C.: U.S. Dept. of Agriculture, Natural Resources Conservation Service, Resource Economics and Social Sciences Division: 1998.

43. Glinka K. Die Typen der Bodenbildung: Ihre Klassifikation und Geographische Verbreitung. Berlin: Verlag von Gebrüder Borntraeger Verlagsbuchhandlung, 1914. 358 p.

44. Helms D. Early Leaders of the Soil Survey. Helms D. (ed al eds.) Profiles in the History of the U.S. Soil Survey. Ames, IO: Iowa State Press, 2002, pp. 19-64.

45. Hilgard E.W. Soils: their formation, properties, composition, and relations to climate and plant growth in the humid and arid regions. New York and London, Macmillan, 1906.

46. Iarilov A.A. Po povodu vtorogo mezhdunarodnogo agrogeologicheskogo s"ezda v Stockgol'me. Pochvovedenie, 1910, no. 4, pp. 367-383.

47. Kellogg C.E. Soil and Society. Soils and Men. Yearbook of Agriculture, 1938.

48. Krassnof A.N. The 'Black earth' of the steppes of Southern Russia. Bulletin of the Geological Society of America, 1892, vol. 3, pp. 68-81.

49. Margerie E. de and Raveneau L. La cartographie a l'Exposition universelle de 1900. Annales de geographie, 1900, no. 9, pp. 402-407.

50. Meunier S. Le Trimestre scientifique. La Nouvelle Revue, 1889, vol. 61, pp. 121-139. 
51. Michéli E. and Fuchs M. Bridging the Centuries: 1909-2009. Centennial meetings on the occasion of the 100th anniversary of the 1st International Conference of Agrogeology. Agrokémia és Talajtan, 2010, vol. 59, no. 1. pp. 195-202.

52. Moon D. and Landa E.R. The Centenary of the Journal Soil Science: Reflections on the Discipline in the United States and Russia Around a Hundred Years ago. Soil Science, 2017, vol. 182, no. 6/7. (forthcoming).

53. Ototskii P.V. Science of Soils. Experiment Station Record, 1899-1900, vol. 11, p. 434.

54. Ototzky P. Guide scientifique sommaire de la section pédologique russe à l'Exposition Universelle de Paris. St Peterburg: Ministère de l'Agriculture et des Domaines, 1900.

55. Selcer P. Patterns of Science: Developing Knowledge for a World Community at Unesco: Ph.D. Dissertation. University of Pennsylvannia, 2011, p. 364.

56. Sibirtzew V.N. (sic) Étude des sols de la Russie. Avec une carte et deux planches. Congrès géologique Internationale compte rendu de la VII session, vol. 2. St. Petersbourg: Imprimerie de M. Stassuléwitsch, 1899, pp. 74-125.

57. Simonson R.W. Early Teaching in USA of Dokuchaiev Factors of Soil Formation. Soil Science Society of America Journal, 1997, vol. 61, pp. 11-16.

58. Simonson R.W. Historical highlights of soil survey and soil classification with emphasis on the United States, 1899-1970. Wageningen, The Netherlands: International Soil Reference and Information Centre, 1989.

59. Sovietov A. and Adamov N. Contributions to the Study of Russian Soils. Experiment Station Record 1899-1900, vol. 11, p. 623.

60. Tulaïkoff N.M. The Genetic Classification of Soils. The Journal of Agricultural Science, 1908 , no. 3, pp. 80-85.

61. Vanderford C.F. The Soils of Tennessee. Tennessee Agricultural Experiment Station Bulletin, 1897, vol. 10, no. 3 .

62. Vtorov I.P. Soil as a museum exhibit in Russia. 13th International ERBE Symposium: Cultural Heritage in Geosciences, Mining and Metallurgy, Libraries - Archives - Museums: Proceedings, ed. Daniel Harvan. Banská Štiavnica: Slovak Mining Museum Banská Štiavnica, 2016, pp. 238-240.

For citation: Moon David The international dissemination of Russian genetic soil science (pochvovedenie), 1870s - 1914. Historia provinciae - the journal of regional history, 2018, vol. 2, no. 1, pp. 75-91. DOI: 10.23859/2587-8352-2018-2-1-5 